\title{
Migration Linguistics: Theoretical and Methodological Approaches to the Formation of the Direction
}

\author{
Shustova Svetlana Viktorovna ${ }^{1}$ \\ Professor, Perm State National Research University, \\ Perm, Russia. \\ (date of receiving: March, 2020; date of acceptance: July, 2020)
}

\begin{abstract}
Migration researchers deal with various aspects of the proposed topics: political, economic, sociological, legal, cultural, psychological. In this regard, approaches to the definition of the concept of "migration" vary. It is not only the definition, which is a problem but also the determination of and finding the key concepts of migration linguistics such as, integration, acculturation, identity. The lack of a unified term system, and as a consequence the divergent use of the concepts of migration linguistics in various scientific fields, complicates the modeling of both migration processes and their key concepts. The object of migration linguistics is not only a model of dynamic language processes, not only a model of migration discourse, but also such aspects as motivation, circumstances, migration factors, consequences of migration processes. Each of these aspects can represent an independent sphere of research.
\end{abstract}

Keywords: Migration Linguistics, Migration, Migration Discourse, Contact Linguistics, Migration Processes.

1. E-mail: lanaschust@mail.ru; ORCID:0000-0002-8318-7864 


\title{
Миграционная лингвистика: теоретико-методологические подходы к формированию направления
}

\section{Шустова Светлана Викторовна ${ }^{1}$}

Профессор, Пермский государственный национальный исследовательский

$$
\begin{aligned}
& \text { университет, } \\
& \text { Пермь, Россия. }
\end{aligned}
$$

(дата получения: март 2020 г.; дата принятия: июль 2020 г.)

\begin{abstract}
Аннотация
В фокусе внимания исследователей миграционных процессов находятся различные аспекты предлагаемой тематики: политические, экономические, социологические, правовые, культурологические, психологические. В связи с этим и подходы к определению понятия «миграция» варьируются. Проблема заключается не только и не столько в дефиниции, а в определении и выявлении ключевых концептов миграционной лингвистики, таких как интеграция, аккультурация, идентичность. Отсутствие единой терминосистемы, а как следствие дивергентное использование концептов миграционной лингвистики в различных научных направлениях усложняют моделирование как миграционных процессов, так и их ключевых концептов. Объектом миграционной лингвистики становится не только модель динамических языковых процессов, не только модель миграционного дискурса, но и такие аспекты как мотивация, обстоятельства, факторы протекания миграции, последствия миграционных процессов. Каждый из названных аспектов может представлять самостоятельную сферу исследования.
\end{abstract}

Ключевые слова: Миграционная Лингвистика, Миграция, Миграционный Дискурс, Контактная Лингвистика, Миграционные Процессы.

1. E-mail: lanaschust@mail.ru; ORCID:0000-0002-8318-7864 


\section{Введение}

В Пермском государственном национальном исследовательском университете группой исследователей разрабатывается новое направление в лингвистике - миграционная лингвистика. Коллектив авторов, включая коллег из Москвы, Томска, Волгограда, Германии, решил внести свой небольшой вклад в развитие лингвистической мысли, развивая позиции отечественных и зарубежных исследователей. Работа автора статьи в области миграционной лингвистики, без упоминания данного названия, началась давно, и представлена в ряде публикаций, посвященных анализу лингвистического ландшафта и влияния глобализационных процессов на его развитие. Коллективом авторов опубликовано три монографии, посвященные разным аспектам формирующегося направления (Миграционная лингвистика ... 2019а, Миграционная лингвистика ... 2019б, Миграционная лингвистика ... 2020). Кроме того, в 2019 г. был опубликован первый номер научного журнала «Миграционная лингвистика» (2019). В предлагаемой статье рассматриваются основные подходы и принципы, которыми руководствуется автор статьи.

Тематика миграции становится наиболее актуальной в области лингвистических исследований особенно в последнее десятилетие. Для обозначения этой сферы все чаще исследователи прибегают к понятию «миграционная лингвистика» (Migrationslinguistik). Причиной становления миграционной лингвистики как самостоятельного направления в лингвистической науке стал факт массивных, многообразных миграционных движений, возникающих в мобильном и глобализирующемся мире. А на основе этих глобальных процессов особую значимость приобретает языковая динамика и ее релевантность для лингвистики в целом.

Отсутствие единой терминосистемы, а как следствие дивергентное использование концептов миграционной лингвистики в различных научных направлениях усложняют моделирование как миграционных процессов, так и их ключевых концептов. Объектом миграционной лингвистики становится не 
только модель динамических языковых процессов, не только модель миграционного дискурса, но и такие аспекты как мотивация, обстоятельства, факторы протекания миграции, последствия миграционных процессов.

Феномен миграции изучается в рамках следующих направлений: психология миграции (Хухлаев 2009), психоанализ миграции (Осадчий и др. 2018), этнология миграции (Черниенко 2017), миграционная лингвистика (Зубарева 2018. 420-422; 2019; Плюснина, Шалгина 2018. 21-25; Krefeld 2004, Gugenberger 2018, Sprachen in mobilisierten Kulturen ... 2011), история миграции (миграционная история) (Ключевский 1995; Ионцев 2014), миграциология (Алешковский, Ионцев 2015), политическая миграциология (Ефимов 2005).

\section{Основная часть}

В сфере миграционной лингвистики речь идет о вариативности языка / речи как способности языка создавать конкурирующие средства выражения на всех уровнях (фонетическом, морфемном, лексическом, синтаксическом, стилистическом) под воздействием внешних причин. Вариативность является одним из важных факторов развития языка и приложима как к языку в целом, так и к различным формам его существования. Это позволяет говорить об универсальном характере вариативности и варьирования. Если продолжать рассуждения относительно варьирования, то следует иметь в виду формальный (структурный), семантический и функциональный аспекты. Прежде всего, в силу того, что данные аспекты обусловлены знаковой природой языковых единиц, их формой, значением и функцией.

Важный вклад в развитие миграционной лингвистики внес Т. Крефельд (Krefeld 2004). Исследователь предложил системную концептуализацию миграционной лингвистики. Особое внимание сфокусировано на вариативной и пространственной лингвистике. 
Теоретической задачей, которую мы ставим перед собой в предлагаемом исследовании - это определение объекта, предмета, цели и задач миграционной лингвистики.

Объектом миграционной лингвистики могут выступать язык мигрантов, моделирование динамических языковых процессов, обусловленных миграционными процессами и моделирование миграционного дискурса.

Предметом миграционной лингвистики могут быть определены модель миграционного дискурса; формирование базовых категорий миграционной лингвистики; формирование и развитие теоретико-методологической базы; разработка системы методов миграционной лингвистики.

Задачи миграционной лингвистики:

1) выявление пространственно специфических и контактных лингвистических аспектов взаимодействия языков различных этносов, проживающих на одной территории (пиджинизация, креолизация);

2) описание взаимодействия национальных, титульных языков и языковых анклавов; выявление критериев сопоставления;

3) разработка типологии языковых анклавов;

4) характеристика положительных и отрицательных сторон мобильности этносов в лингвистическом аспекте;

5) моделирование лингвокультурной полифонии языковой картины мигранта;

6) анализ причин языковой агрессии со стороны титульной нации и мигрантов;

7) сравнительный анализ нормативно-правовых актов стран в области языковой политики в аспекте выделения участников, их прав и обязанностей, включая организации; 
8) разработка типологии языковых ситуаций, возникновение которых обусловлено миграционными процессами и желанием мигрантов сохранить свою идентичность;

9) определение роли политической лингвистики, контактной лингвистики, вариативной лингвистики, пространственной лингвистики и лингвоэкологии в формировании миграционной лингвистики;

10) анализ туристической миграции в лингвистическом аспекте;

11) разработка типологии коммуникационных пространств, обусловленных миграционной мобильностью;

12) анализ динамических процессов в языке (на всех уровнях), обусловленных миграционными процессами;

13) введение понятия «мобильное многоязычие»;

14) моделирование процессов ослабления речевой конфликтогенности;

15) моделирование миграционных процессов в лингвистическом аспекте.

Миграция является неотъемлемой частью процесса межкультурной коммуникации. По словам Е.С. Ашнина, «увеличение миграционных потоков обострили уже существующие и создали новые проблемы... наиболее важными из которых являются обеспечение продуктивного межкультурного взаимодействия и построение мультикультурного общества» (Ашнин 2012. 136).

П. Керсвилл отмечает, что миграция является основной причиной изменения титульного языка того или иного этноса, вызванного многочисленными межкультурными контактами. Принимающее общество неизбежно вбирает те или иные черты повседневного быта, традиционные модели организации жизни, элементы художественной культуры и литературы, фольклора, духовные ценности, особенности этикета, языковые 
обороты, лексические и грамматические средства. Миграция формирует этнолингвистическое меньшинство, которое вносит новое и трансформирует титульный язык (Kerswill 2006. 8).

Но при этом теория межкультурной коммуникации как наука не ставит перед собой задачу объяснить и решить проблемы, которые возникают в языке при больших миграционных потоках.

В области изучения динамических процессов в языке в миграционной лингвистике можно было бы сконцентрировать внимание на следующих аспектах, которые, в свою очередь, затрагиваются в других направлениях лингвистической науки.

1) политическая лингвистика: образ мигранта, образ принимающей страны, образ лидера страны;

2) лингвоэкология: нормативно-правовые акты в области языковой политики, борьба за чистоту языка титульной нации;

3) теория коммуникации: типология коммуникационных пространств, обусловленных миграционной мобильностью;

4) когнитивная лингвистика: концепты «иммигрант», «эмигрант», «переселенец», «беженец», «лимитчик», «мигрант», «миграция»; переключение языковых кодов;

5) переводоведение, контактная лингвистика: переключение языковых кодов;

6) межкультурная коммуникация: туристическая миграция, образ принимающей стороны, образ мигранта, образ лидера страны, межэтнические конфликты, мобильность этносов, кросскультурные контакты, языковая картина мира мигранта;

7) паремиология: паремийные трансформанты;

8) социо- и психолингвистика: языковая политика, языковые контакты, языковая ситуация, языковые анклавы, языковая 
экспансия, мобильное многоязычие, речевая конфликтогенность; развитие теории адстрата, суперстрата, субстрата;

9) лексическая семантика, контактная лингвистика: заимствования, неологизация, метафоризация;

10) лингвогеография, моделирование миграционных процессов в лингвистическом аспекте: количество этносов, количество говорящих на языке титульной нации и языке мигрантов, современный лингвистический ландшафт, языковые анклавы.

11) метафорология: образ мигранта, образ принимающей страны, образ лидера страны, реалии принимающей стороны (лексикосемантические трансформации);

12) вариативная лингвистика, вариотология: инвариантное и вариантное в языке;

13) дискурсология: моделирование миграционного дискурса

14) моделирование концептуального поля МИГРАЦИЯ.

Как мы уже отмечали, базовым концептом миграционной лингвистикия является МИГРАЦИЯ. Миграция, беженцы, иммигранты входят в общий социокультурный и языковой контекст жизни общества. Это обусловливает необходимость теоретического обоснования процессов, возникающих в результате возросших масштабов миграции населения и связанных с ней политических последствий, дополнительных способов языковой номинации и формирования некоторых акцентов на определенных фрагментах новой языковой реальности. Миграционный дискурс рассматривается как вид социальной практики, поскольку его формируют социальные структуры, социальные практики, социальные агенты, участники, вовлеченные в социальные события. 


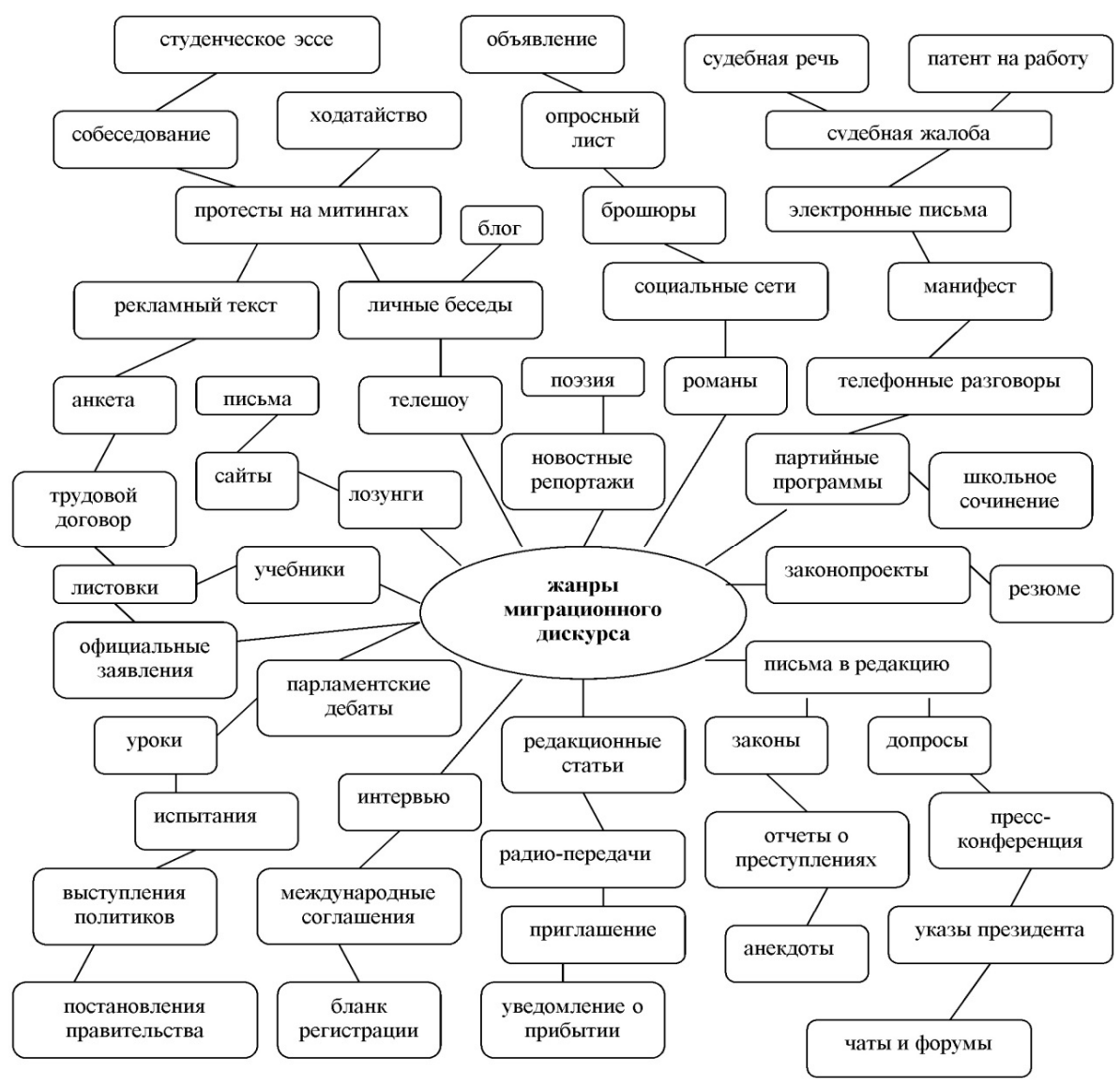

Схема 1. Жанровая модель миграционного дискурса

по Е.О. Зубаревой (2019)

Ю.С. Степанов предлагает следующую дефиницию: «... дискурс - это «язык в языке», но представленный в виде особой социальной данности. Дискурс существует, прежде всего, и главным образом, в текстах, но таких, за которыми встает особая грамматика, особый лексикон, особые правила словоупотребления и синтаксиса, особая семантика, в конечном счете особый мир. В мире всякого дискурса действуют свои правила синонимичных замен, свои правила истинности, свой этикет. Это - «возможный 
(альтернативный) мир в полном смысле этого логико-философского термина»») (Степанов 1995).

Дискурсивное пространство мыслится нами как среда сосуществования и функционирования определенных дискурсов, объединенных по какому-либо принципу. < ..> Дискурсивное пространство понимается не как вместилище, в которое помещены дискурсы, в котором они «расположены», оно понимается как сложная система, параметры которой заданы возможностью объединения дискурсов (Плотникова 2018. 31 - 61).

Миграционный дискурс - коммуникативный процесс, участники которого стремятся:

Блок 1. Система ценностей: адаптироваться в принимающей стране; принять законодательство страны; оставаться в своей конфессии или изменить вероисповедание; освоить язык принимающей страны; определить для себя и своей семьи выгоды от пребывания на территории этой страны; принять решение о пребывании самостоятельно; адаптироваться к условиям проживания в одиночку, семьей, группой; решить экономические вопросы жизнеобеспечения; дать детям образование; обеспечить семью медицинским обслуживанием; принять культуру титульной нации.

Блок 2. Система ценностей: создать анклав (экономический, политический); создать языковой анклав; создавать условия для укрепления и расширения своего вероисповедания; не осваивать язык титульной нации; определить для себя и своей семьи выгоды от пребывания на территории принимающей страны; принять решение под давлением (из-за страха, из-за угроз); решать экономические вопросы жизнеобеспечения; дать детям образование; обеспечить семью медицинским обслуживанием; игнорировать культуру титульной нации (насаждать свою культуру).

При рассмотрении подходов, связанных со становление миграционной лингвистики, возникает вопрос о связи миграционной лингвистики и 
контактной лингвистики. Ж. Багана, Е.В. Хапилина в своей монографии «Контактная лингвистика. Взаимодействие языков и билингвизм» (2010) представили глубокую теоретическую базу разрабатываемого направления, а также предприняли попытку выявления отличий контактной лингвистики от социолингвистики (Багана, Хапилина 2010).

Исследователи отмечают, что социолингвистика нацелена на описание взаимодействия языков и культур, становление контактной лингвистики обусловлено расширяющимися интеграционными процессами и обращением ученых к вопросу о языковых контактах. С точки зрения синхронии логично рассматривать соприкосновение сосуществующих языковых систем (владение несколькими языковыми кодами, несколькими языками, наличие нескольких государственных языков в один период времени). В диахроническом аспекте могут быть раскрыты основные способы сосуществования языков, механизмы их взаимодействия, изменения на языковых уровнях и т.д.

В ходе языковых контактов актуализируются такие процессы как конвергенция, заимствование, интерференция, контаминация. Исследователи Ю.В. Балакина, А.В. Соснин в сферу контактной лингвистики включают такие категории как языковой контакт, билингвизм, заимствование и интерференция, переключение кодов, пиджин и креольские языки (Балакина, Соснин 2015. 5).

Языковой контакт актуализируется в результате взаимодействия двух или более языков или их разновидностей (диалектов, арго, профессиональной лексики). Языковая вариативность представляет собой объективное имманентное свойство языковой системы, затрагивающее все выделяемые в языке подсистемы и единицы плана выражения и плана содержания, в синхронии и диахронии (Дубровина 2015. 44).

В рамках контактной лингвистики, как и в рамках миграционной лингвистики могут находиться вопросы, связанные с лингвотолерантностью (см., например, Шемчук 2013). Лингвотолерантность (толерантность языка) 
проявляется в принятии иноязычных единиц в словарный состав языка. В качестве примера могут послужить многочисленные заимствования, используемые в молодежной субкультуре европейских стран.

Ключевым понятием лингвотолерантности является «словарный импорт».

Ключевым понятием контактной лингвистики - «заимствование».

Лингвотолерантность следует отличать от эколингвистики, поскольку последняя ставит задачу сохранения своеобразия отдельных языков и диалектов. Эколингвистика предполагает деятельностный подход к поддержанию самобытности языка. Лингвотолерантность пассивна и ограничивается согласием со всеми языковыми изменениями. Причина возникновения эколингвистики - пуризм - движение за чистоту языка. Лингвотолерантность объединяет с контактной лингвистикой категория заимствования, в связи с этим лингвотолерантность необходимо включать в сферу контактной лингвистики (Багана, Хапилина 2010. 95-98).

В конце XVIII начале XIX вв. изменилось положение в отношении языковых контактов. На протяжении XIX в. сравнительно-историческое языкознание становится основной лингвистической дисциплиной. В фокусе внимания исследователей находятся процессы языковой дивергенции. Конвергентные процессы, контактные процессы отошли на задний план. Так, Г. Пауль рассматривает семантические сдвиги в лексическом значении слов родного языка под влиянием слов другого языка, о структурном калькировании, о заимствовании суффиксов и флексий, а главное, указывает на роль двуязычия - индивидуального и коллективного - как главного фактора, делающего возможным влияние одного языка на другой (Пауль 1960).

Австрийский языковед Г. Шухардт внес неоценимый вклад в изучение языковых контактов. Для ученого смешение языков было основополагающей чертой истории любого языка («Slawo-Deutsches und Slawo-Italienisches, 1884, 
1926). Г. Шухардт впервые обратился к явлению, в последствии получившему название языковой интерференции и высказал чрезвычайно интересные мысли о двуязычии.

Проблемы языковых контактов представлены в трудах Л.В. Щербы (Щерба 1958, 2007).

Ситуация языкового контакта не всегда может иметь отношение к миграционной лингвистике, с одной стороны, однако, с другой стороны, не все языковые явления, фиксируемые в условиях языковых контактов, могут быть объяснены с позиций миграционной лингвистики.

В концепциях Т. Крефельда (2004) и Е. Гугенбергер (2018) языковое пространство рассматривается как одномерное, статическое, характеризуется одноязычием и оседлостью говорящих; не фиксируется аллохтонная вариативность и многоязычие. Т. Крефельд развивает динамическую многомерную концепцию коммуникативного пространства, которое может стать моделью для миграционных коммуникативных пространств во всем их многообразии (Krefeld 2004. 19).

Чрезвычайно интересной областью миграционной лингвистики может стать ситуация многоязычия у этнических меньшинств. В специальной литературе они называются по-разному: мигрантские меньшинства (Migrationsminderheiten) или аллохтоны (allochtone Minderheiten), меньшинства, противопоставляемые аутохтонным меньшиствам (autochtonne Minderheiten) или говорящие на исторически региональном языке (Sprecher historischer Regionalsprache) (Gugenberger 2018. 49).

Для Е. Гугенбергер объектом миграционной лингвистики являются психические процессы, протекающие в сознании, которые являются основополагающими для понимания восприятия, толкования и интерпретации знаков внешнего мира индивидуумом, в конкретном контексте исследования мигрантом. 


\section{Заключение}

Таким образом, объектом миграционной лингвистики могут стать динамические языковые процессы, обусловленные миграционными процессами, и моделирование миграционного дискурса. В качестве предмета миграционной лингвистики могут быть определены модель миграционного дискурса, формирование базовых категорий миграционной лингвистики, формирование и развитие теоретико-методологической базы, разработка системы методов миграционной лингвистики, разработка процедур снижения языковой конфронтации. Языковая конфронтация, или языковое противостояние, рассматривается как противостояние групп людей, причиной которого являются языковые проблемы, обычно стремление демографически и/ или социально доминирующего этноса ущемить языковые права других этнических групп или нежелание разных этнических групп изучать язык доминирующего этноса. Определить позиции пересечения и выявить положительные и отрицательные факторы, связанные с миграционными процессами, - задача, которая может быть решена только при условии взаимодействия специалистов разных областей

\section{Литература}

1- Алешковский И.А., Ионцев В.А. (2015). Управление международной миграцией в условиях глобализащии // Век глобализации. № 1(15). С. 75-87.

2- Ашнин Е.С. (2012). Сочиолингвистические аспекты межкультурной коммуникации в Германии // Вестник Волгоградского государственного университета. Серия 9: Исследование молодых ученых. № 10. С. 136-138.

3- Багана Ж., Хапилина Е.В. (2010). Контактная лингвистика. Взаимодействие языков и билингвизм. -М.: Флинта, Наука. 128 с.

4- Балакина Ю.В., Соснин А.В. (2015). Теоретические основы переключения кодов и функиионирования заимствований с позищий контактной лингвистики // Вестник Воронежского государственного университета. Серия: Лингвистика и межкультурная коммуникация. № 2. С. 5-11.

5- Дубровина С.Н. (2015). Вариативность как универсальное свойство языка // Верхневолжский филологический вестник. № 3. С. 44-48. 
6- Зубарева Е.О. (2019). Языковая репрезентация концепта МИГРАЦИЯ // Миграционная лингвистика в современной научной парадигме. Коллективная монография / Зубарева Е. О., Исаева Е. В., Иценко А. В., Костева В. М., Мощанская Е. Ю., Шустова С. В. / Научный редактор доктор филологических наук, профессор Т. И. Ерофеева; Пермь: Пермский гос. нац. иссл. ун-т, С. $65-$ 112. https://naukblog.blogspot.com,

7- Зубарева Е.О. (2018). Номинативное поле концепта «мигрант» // Мир науки, культуры, образования. № 4(71). С. 420-422.

8- Ефимов Ю.Г. (2005). Политическая миграциология. Ставрополь: СевероКавказский государственный технический университет. 160 с.

9- Ионцев В.А. Интеграция мигрантов - эффективный путь устранения неравенства и ксенофобии в принимающем обществе // Вопросы управления. 2014, № 1(26). С. 127-132.

10- Ключевский В.О. (1995). Русская история. Полный курс лекций в трех книгах. Книга 1. -М.: Мысль. 567 с.

11- Миграционная лингвистика в современной научной парадигме. (2019). Коллективная монография / Зубарева Е. О., Исаева Е. В., Иценко А. В., Костева В. М., Мощанская Е. Ю., Шустова С. В. / Научный редактор доктор филологических наук, профессор Т. И. Ерофеева; Пермь: Пермский гос. нац. иссл. ун-т, 2019. 163 c. https://naukblog.blogspot.com,

12- Миграционная лингвистика в современной научной парадигме: медиационные практики. (2019а). Монография / Шустова С. В., Желтухина М.Р., Дружинина М.В., Зубарева Е. О., Исаева Е. В., Костева В. М., Черноусова А.С. / Научный редактор доктор филологических наук, профессор А.М. Аматов; Пермь: Пермский гос. нац. иссл. ун-т. 180 c. https://naukblog.blogspot.com,

13- Миграционная лингвистика (2019). Научный журнал. Пермь № 1. https://naukblog.blogspot.com,

14- Миграционная лингвистика в современной научной парадигме: дискурсивные практики, перевод, дидактика. (2020). Монография / Шустова С. В., Зубарева Е. О., Хорошева Н.В., Костева В. М., Мощанская Е.Ю., Киндеркнехт А.С., Köck Jh. / Научный редактор доктор филологических наук, профессор О.А. Радченко; Пермь: Пермский гос. нац. иссл. ун-т. 180 с. https://naukblog.blogspot.com,

15- Осадчий Г.В., Осадчая Г.И., Андреев Э.М., Юдина Т.Н. и др. (2018). Проиессы евразийской интеграции: социально-политическое измерение. -М.: Издательский дом БИБЛИО-ГЛОБУС. 374 с.

16- Пауль Г. (1960). Принц̧ипь истории языка. -М.: Изд-во иностранной литературы. 501 с.

17- Плотникова С.Н. (2018). Дискурс и дискурсивное пространство // Дискурс как универсальная матрица вербального взаимодействия. Отв. ред. О.А. Сулейманова. -М.: ЛЕНАНД. С. 31-61. 
18- Плюснина Е.М., Шалгина Е.А. (2018). Сценарий каузативной ситуащии с глаголом aimer // Евразийский гуманитарный журнал. № 3. С. 21-25.

19- Степанов Ю.С. (1995). Альтернативный мир. Дискурс, Факт и принцип причинности // Язык и наука конца 20 века. Сборник статей. М.: Российский государственный гуманитарный университет. 432 с.

20- Хухлаев О.Е. (2009). Этнонациональные установки московских страшеклассников в условиях совместного обучения с мигрантами // Психологическая наука и образование. № 1. С. 5-13.

21- Черниенко Д.А. (2017). Восточнославянские народы Удмуртии. Ижевск: Шелест. 223 с.

22- Шемчук Ю.М. (2013). Лингвотолерантность в эпоху глобализации // Вестник Московского государственного гуманитарного университета им. М.А. Шолохова. Филологические науки. № 1. С. 95-98.

23- Щерба Л.В. (1958). Избранные работы по языкознанию и фонетике. Ленинград: Изд-во Ленинградского университета. 183 с.

24- Gugenberger E. (2018). Theorie und Empirie der Migrationslinguistik. Mit einer Studie zu den Galicieen und Galicierinnen in Argentien. Austria: Forschung und Wissenschaft. Literatur und Sprachwissenschaft. B. 21. LiT Verlag. AG GmbH\&Co.KG. Wien. 658 S.

25- Kerswill P. (2006). Migration and language // Klaus Mattheier, Ulrich Ammon \& Peter Trudgill (eds.) Sociolinguistics / Soziolinguistik. An international handbook of the science of language and society. 2nd edn. Vol 3. Berlin: De Gruyter. P. 22712285.

26- Krefeld Th. (2004). Einführung in die Migrationslinguistik. Von der Germania italiana in die Romania multipla. Gunter Narr Verlag. Tübingen. 173 S.

27- Sprachen in mobilisierten Kulturen: Aspekte der Migrationslinguistik. (2011). Hrsg von Th. Stehl. Universitätsverlag Potsdam. URL: https://www.google.com/ search?tbm=bks\&q=Migrationslinguistik (дата обращения: 03.05.2018).

\section{Bibliography}

1- Aleshkovskij I.A., Ioncev V.A. (2015). Upravlenie mezhdunarodnoj migraciej v uslovijah globalizacii // Vek globalizacii. № 1(15). S. 75-87.

2- Ashnin E.S. (2012). Sociolingvisticheskie aspekty mezhkul'turnoj kommunikacii v Germanii // Vestnik Volgogradskogo gosudarstvennogo universiteta. Serija 9: Issledovanie molodyh uchenyh. № 10. C. 136-138.

3- Bagana Zh., Hapilina E.V. (2010). Kontaktnaja lingvistika. Vzaimodejstvie jazykov $i$ bilingvizm. -M.: Flinta, Nauka. $128 \mathrm{~s}$. 
4- Balakina Ju.V., Sosnin A.V. (2015). Teoreticheskie osnovy perekljuchenija kodov $i$ funkcionirovanija zaimstvovanij s pozicij kontaktnoj lingvistiki // Vestnik Voronezhskogo gosudarstvennogo universiteta. Serija: Lingvistika i mezhkul'turnaja kommunikacija. № 2. S. 5-11.

5- Dubrovina S.N. (2015). Variativnost' kak universal'noe svojstvo jazyka // Verhnevolzhskij filologicheskij vestnik. № 3. S. 44-48.

6- Zubareva E.O. (2019). Jazykovaja reprezentacija koncepta MIGRACIJa // Migracionnaja lingvistika $\mathrm{v}$ sovremennoj nauchnoj paradigme. Kollektivnaja monografija / Zubareva E. O., Isaeva E. V., Icenko A. V., Kosteva V. M., Moshhanskaja E. Ju., Shustova S. V. / Nauchnyj redaktor doktor filologicheskih nauk, professor T. I. Erofeeva; Perm': Permskij gos. nac. issl. un-t, C. 65-112. https://naukblog.blogspot.com,

7- Zubareva E.O. (2018). Nominativnoe pole koncepta «migrant»// Mir nauki, kul'tury, obrazovanija. № 4(71). S. 420-422.

8- Efimov Ju.G. (2005). Politicheskaja migraciologija. Stavropol': Severo-Kavkazskij gosudarstvennyj tehnicheskij universitet. $160 \mathrm{~s}$.

9- Ioncev V.A. Integracija migrantov - jeffektivnyj put' ustranenija neravenstva $i$ ksenofobii v prinimajushhem obshhestve // Voprosy upravlenija. 2014, № 1(26). S. $127-132$.

10- Kljuchevskij V.O. (1995). Russkaja istorija. Polnyj kurs lekcij v treh knigah. Kniga 1. -M.: Mysl'. $567 \mathrm{~s}$.

11- Migracionnaja lingvistika v sovremennoj nauchnoj paradigme. (2019). Kollektivnaja monografija / Zubareva E. O., Isaeva E. V., Icenko A. V., Kosteva V. M., Moshhanskaja E. Ju., Shustova S. V. / Nauchnyj redaktor doktor filologicheskih nauk, professor T. I. Erofeeva; Perm': Permskij gos. nac. issl. un-t, 2019. 163 s. https://naukblog.blogspot.com,

12- Migracionnaja lingvistika v sovremennoj nauchnoj paradigme: mediacionnye praktiki. (2019a). Monografija / Shustova S. V. , Zheltuhina M.R., Druzhinina M.V., Zubareva E. O., Isaeva E. V., Kosteva V. M., Chernousova A.S. / Nauchnyj redaktor doktor filologicheskih nauk, professor A.M. Amatov; Perm': Permskij gos. nac. issl. un-t. $180 \mathrm{~s}$. https://naukblog.blogspot.com,

13- Migracionnaja lingvistika (2019). Nauchnyj zhurnal. Perm’ № 1. https://naukblog.blogspot.com,

14- Migracionnaja lingvistika v sovremennoj nauchnoj paradigme: diskursivnye praktiki, perevod, didaktika. (2020). Monografija / Shustova S. V., Zubareva E. O., Horosheva N.V., Kosteva V. M., Moshhanskaja E.Ju., Kinderkneht A.S., Köck Jh. / Nauchnyj redaktor doktor filologicheskih nauk, professor O.A. Radchenko; Perm': Permskij gos. nac. issl. un-t. $180 \mathrm{~s}$. https://naukblog.blogspot.com,

15- Osadchij G.V., Osadchaja G.I., Andreev Je.M., Judina T.N. i dr. (2018). Processy evrazijskoj integracii: social'no-politicheskoe izmerenie. -M.: Izdatel'skij dom BIBLIO-GLOBUS. $374 \mathrm{~s}$.

16- Paul' G. (1960). Principy istorii jazyka. -M.: Izd-vo inostrannoj literatury. $501 \mathrm{~s}$. 
17- Plotnikova S.N. (2018). Diskurs $i$ diskursivnoe prostranstvo // Diskurs kak universal'naja matrica verbal'nogo vzaimodejstvija. Otv. red. O.A. Sulejmanova. M.: LENAND. S. 31-61.

18- Pljusnina E.M., Shalgina E.A. (2018). Scenarij kauzativnoj situacii s glagolom aimer // Evrazijskij gumanitarnyj zhurnal. № 3. S. 21-25.

19- Stepanov Ju.S. (1995). Al'ternativnyj mir. Diskurs, Fakt i princip prichinnosti // Jazyk i nauka konca 20 veka. Sbornik statej. -M.: Rossijskij gosudarstvennyj gumanitarnyj universitet. $432 \mathrm{~s}$.

20- Huhlaev O.E. (2009). Jetnonacional'nye ustanovki moskovskih strasheklassnikov v uslovijah sovmestnogo obuchenija s migrantami // Psihologicheskaja nauka i obrazovanie. № 1. S. 5-13.

21- Chernienko D.A. (2017). Vostochnoslavjanskie narody Udmurtii. Izhevsk: Shelest. $223 \mathrm{~s}$.

22- Shemchuk Ju.M. (2013). Lingvotolerantnost' v jepohu globalizacii // Vestnik Moskovskogo gosudarstvennogo gumanitarnogo universiteta im. M.A. Sholohova. Filologicheskie nauki. № 1. S. 95-98.

23- Shherba L.V. (1958). Izbrannye raboty po jazykoznaniju i fonetike. Leningrad: Izdvo Leningradskogo universiteta. $183 \mathrm{~s}$.

24- Gugenberger E. (2018). Theorie und Empirie der Migrationslinguistik. Mit einer Studie zu den Galicieen und Galicierinnen in Argentien. Austria: Forschung und Wissenschaft. Literatur und Sprachwissenschaft. B. 21. LiT Verlag. AG GmbH\&Co.KG. Wien. 658 S.

25- Kerswill P. (2006). Migration and language // Klaus Mattheier, Ulrich Ammon \& Peter Trudgill (eds.) Sociolinguistics / Soziolinguistik. An international handbook of the science of language and society. 2nd edn. Vol 3. Berlin: De Gruyter. P. 22712285 .

26- Krefeld Th. (2004). Einführung in die Migrationslinguistik. Von der Germania italiana in die Romania multipla. Gunter Narr Verlag. Tübingen. $173 \mathrm{~S}$.

27- Sprachen in mobilisierten Kulturen: Aspekte der Migrationslinguistik. (2011). Hrsg von Th. Stehl. Universitätsverlag Potsdam. URL: https://www.google.com/ search?tbm=bks\&q=Migrationslinguistik (data obrashhenija: 03.05.2018).

HOW TO CITE THIS ARTICLE

Шустова С. В. (2020). Migration Linguistics: Theoretical and Methodological Approaches to the Formation of the Direction. Issledovatel'skiy Zhurnal Russkogo Yazyka i Literatury, 8(2), 107-125.

DOI: $10.29252 /$ iarll.16.113

URL: http://journaliarll.ir/index.php/iarll/article/view/124 


\title{
رويكردهاى نظرى و روششناختى در شكل گيرى زبانشناسى مهاجرت
}

\author{
سو تلانا ويكتورونا شوستووا'

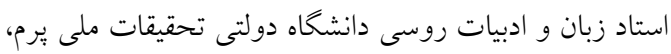

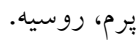 \\ (تاريخ دريافت: مارس •r.r؟ تاريخ بذيرش: زوئيه •r.r)
}

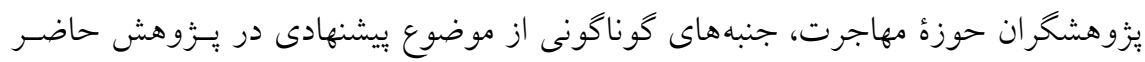

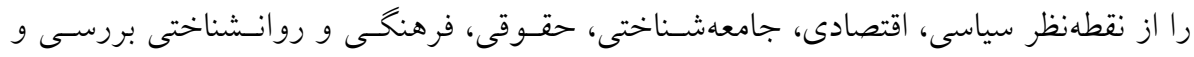

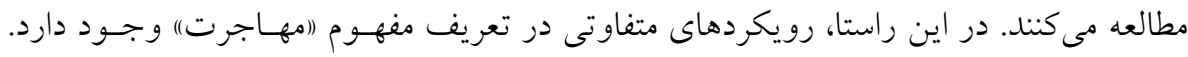

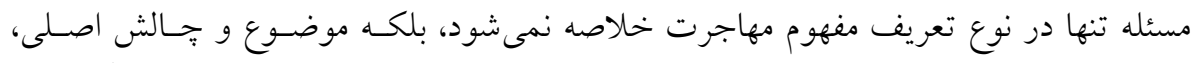

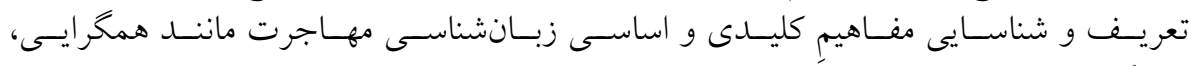

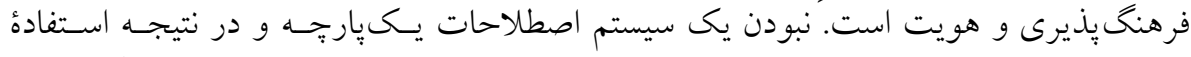

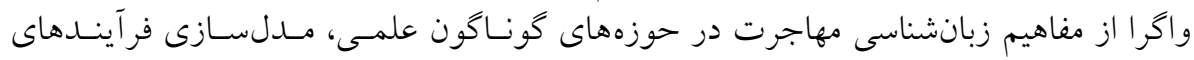

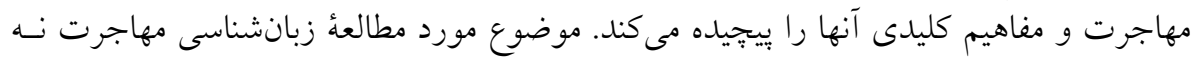

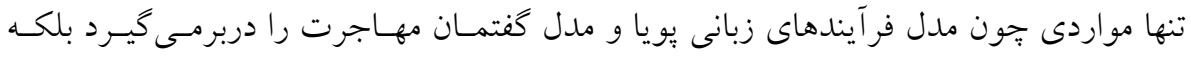

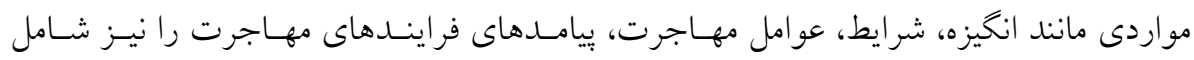

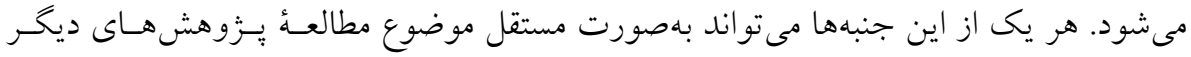

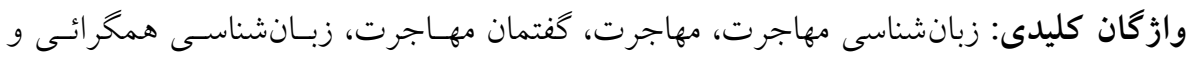

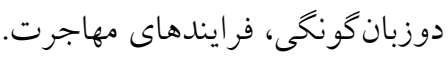

